\title{
Bankruptcy in Indian Private Sector Banks: A Neural Network Analysis
}

\author{
Surbhi Dhama*
}

\begin{abstract}
This paper aims to predict the bankruptcy in Indian private banks using financial ratios such as ROA, GNPA, EPS, PAT, and GNP of the country. This paper also explains the importance of Ohlson's number, Graham's number and Zmijewski number as the major predictors of bankruptcy while developing a model using neural networks. For the prediction, the financial data for private sector banks of India such as HDFC, HDFC, ICICI, AXIS, YES bank, KOTAK MAHINDRA Bank, FEDERAL BANK, INDUSIND Bank, RBL and KARUR VYSYA for the last 10 years from 2010-2019 have been analysed. The model developed during the research will help the financial institutions and banks in India to understand the economic condition of the banking industry.
\end{abstract}

Keywords: Bankruptcy Prediction, Neural Networks, Financial ratios.

\section{Introduction}

The high pace of technology, environmental changes, and their impact on global business has resulted in increased economic volatility, in a way that limits the competitive standards of economic organizations. This is especially so, in terms of gaining interest and increase in the risks of bankruptcy. (Mansouri, Nazari \& Ramazani, 2016) Additionally, the recent global recession is an example of an

\footnotetext{
* Relationship Manager-Business Banking, IDFC First Bank, India; dhamasurbhi@gmail.com
} 
economic disaster that occurred due to bankruptcy. Following the financial crisis and the need to enforce Basel III standards, financial solvency has become a top priority for the banking sector, as there are some factors such as management failure, competition, increased NPAs, rising cases of fraud inability to meet regulatory requirements and others that generate the possibility of risk and lead to financial distress. It is necessary to strengthen the rules and procedures relating to the fraudulent transfer of assets. Finally, a system must be implemented to assess cross-border assets. (Pandey, 2016) In summary, from 1947 onwards to the recent introduction of the new Act, the legal and regulatory system for dealing with insolvency and bankruptcy cases has been grossly inadequate. The main focus in the prediction of bankruptcy is to figure out whether or not a financial firm or company is going to go bankrupt. The bankruptcy or financial issue is a forward-looking situation when a financial firm verifies its financial obligations. The main challenge in the prediction of bankruptcy, however, starts with the selection of the technique of prediction. Many recent and sophisticated techniques have been developed for predicting bankruptcy.

However, according to Du Jardin (2010), whatever the method, when the research aims to seek an effective means of improving the accuracy of a prediction, the variables to be included in the models are commonly chosen because they are among those frequently used in the field of financial analysis, and such a set being validated historically through univariate statistical tests. The neural network in prescription Artificial Neural Networks (ANN) is now a solutionbased "vital" research territory, and it is believed that the broad application of these machine learning frameworks will be achieved in the coming years. The ANN algorithm used in this analysis is the Backpropagation Algorithm, which is a supervised learning algorithm and is typically used by a multi-layered perceptron to adjust the weights associated with the neurons in the hidden layer. The results of several studies demonstrated by using computational intelligence provide better precise percentages than using statistical techniques, i.e. with neural network supervised learning so that the preferred method of ANN is backpropagation. Over the past few years, ANNs have also been applied for various accounting applications, especially for predictions of bankruptcy. Generally, the 
results were higher with ANN's methods than with the statistical methods that were the dominant approaches until now.

\section{Literature Review}

This study aims to establish the bankruptcy prediction model for Indian private sector banks as a statistical tool for forecasting bankruptcy in the banking industry of India. Because of this position, this study will build and apply a statistical neural network model for the prediction of bankruptcy in India.

Edward (1968) in his paper explains the importance of using financial ratios in the prediction of bankruptcy. The results obtained from the paper are limited to the specific parameters such as the financial ratios with multiple discriminant analysis. Ohlson (1980) in his paper indicates that it's possible to find the probability of a firm going bankrupt before a particular date by considering the factors such as financial structure, the measure of performance, size of firm and the measure of liquidity, though the evidence lacks the information on the measure of liquidity. Begley, Jog and Ming (1996) in their paper show the weakness of the model of Altman and Ohlson. They showed that their models were not well anticipated when re-estimated, but they also found that the model of Ohlson is stronger than the model of Altman. Nadine (2001) says that among the most common approaches in this type of problem were statistical procedures (multiple discriminant analysis, logit or probit). The main goal is to provide a review of the last ten years' literature, but also to have a larger view than average by evoking bankruptcy causes, symptoms and remedies. Block-lieb \& Janger (2006) in their article try to argue that empirical study of human behavior by cognitive psychologists and behavioral economists undermines the idea that decision-making is motivated exclusively by such costbenefit analysis. Sun (2007) showed that certain variables that can be viewed as non-financial indicators to calculate financial distress such as the failure rate of the company, excessive returns on stocks and market capitalization are used to build a model for predicting bankruptcy. The primary goal of the paper of Bellovary, John, and Giacomino (2007) is to summarize and analyze existing research on bankruptcy prediction studies to facilitate more productive future research in this area. Burke (2007) has sought both to shape the 
direction of reform and to involve conscientious prosecutors in the ongoing innocence dialogue by focusing on debiasing strategies that can be implemented entirely within the province of prosecutors, either as individual practice or as institutional policy. Constand, Richard, and Yazidpour (2010) addresses some other variables to be considered in forecasting financial distress, such as psychological phenomena and values, known as heuristics or mental shortcuts. Y.Wu C Gaunt S. Gray (2010) discusses the prediction of bankruptcy, taking into account excess stock returns and stock price volatility as factors in the model. John, Hilscher and Szilagyi (2010) explain that the forecasts of the model are intuitive about the distressed companies that have suffered losses recently, have high leverage, weak and unpredictable recent returns, have market-to-book rates and low share prices. Jouzbarkand, Aghajani and Khodadabi (2013) analysed two models in their research paper, i.e. Ohlson and Shirata models to classify bankrupt firms. In addition to this, logistic regression is used to evaluate the model's robustness. Singh and Makkar (2015) in their study, used Z-score for four different ratios i.e. working capital to total assets, retained earnings to total assets, earnings before interest and taxes to total assets and equity to a total asset which helped in predicting the financial distress in the time period 2006-2012. Veganzones, David and Severin (2018) did a systematic analysis of the degree of disparity, output loss, and methods of treatment that are provided in the current article. The results show that an imbalanced distribution, in which the minority class constitutes 20 percent, disturbs the output of predictions significantly.

Motamedi (2013) in his paper showed that the required return of protection in this liquidity-adjusted CAPM depends on its expected liquidity as well as on the covariances of its return and liquidity with the return and liquidity of the market. The empirical results illustrated the overall and relative economic importance of these networks and provided evidence of liquidity flight. Vardar (2013) investigates the correlation between banks' cost and benefit efficiency scores in Central and Eastern European countries as well as Turkey and their performance in stock prices to determine whether the efficiency scores are priced in bank stocks accordingly. Bansal and Mohanty (2014) evaluated the output of five banks SBI, AXIS, ICICI, KOTAK MAHINDRA and HDFC using the CAMEL 92 
model based on market capitalization, capital adequacy, asset quality, and earnings. Based on the model, banks are allocated ranks based on performance, where HDFC is ranked first, performing better than the others, and AXIS bank is ranked lowest. Gautam, Joshi, Singh and Kumar (2014) used CAMEL's model and differential analysis in their paper to forecast the performance of six private sector banks, among which HDFC performs the best. Karim (2013) analyzes the performance of five private sector banks in Bangladesh using multiple regression models showing the effect of bank size, credit risk, and operational efficiency. Three indicators, i.e. internal ROA performance, market-based performance calculated by Tobin's $\mathrm{Q}$ model (book value price) and economic indicator. The paper of Malyadri and Sirisha (2015) comprises an analytical study that takes financial ratios as indicators to predict the growth of the banking industry. The results tell us that private sector banks are doing well when compared to the other group of banks in terms of ROA, profitability, etc. M and Chakraborty (2017) in their paper helps us understand how the new banks in the private sector are doing better than the old banks in the private sector. Interest rate, ROA, nonperforming assets, etc. are used as metrics and CAMEL model performance. Chintala (2017) in his paper contrasted the performance of five public and five private sector banks based on their market capitalization using a quota sample model. As measures, T-tests, mean and graphs are used. Banks in the private sector are doing well, as the results show. Bhatia and Mulenga (2019) in their study worked with an objective of finding out the difference, if any, in the value relevance of Earnings Per Share (EPS) and Book Value Per Share (BVPS)between private and public sector banks listed on the Bombay Stock Exchange, India. The findings of this study show that the Earnings Per Share and Book Value Per Share) jointly and individually are positively and significantly related with the market share price of public sector banks, private sector banks, and all banks. Raj (2019) in is paper, used ALTMAN's Z-Score model to check the financial health and bankruptcy risk of 10 Indian banks that comprised 5 private sector and 5 public sector banks by taking the past 5 years data. Here, the Z-Score tells us that after the implementation of Basel III norms, banks performance is better and also, they are out of the risk of financial distress. Tam (1991) in his paper, found out that neural networks approach of machine learning 
is compared with other traditional statistical tools to present the empirical results in predicting the bankruptcy of banks. Though the neural networks is a competitive instrument in predicting the financial condition of banks, it has its own limitations. Wilson and Sharda (1994) explain the advantage of Artificial Neural Networks as a machine learning tool over the traditional statistical techniques, especially when it comes to the prediction of bankruptcy which requires the back-propagation method to produce efficient results. Piramuthu, Ragavan, and Shaw (1998) in their paper discuss various qualities in the use of neural networks, which are mentioned along with the disadvantage that the back- propagation is found to be slow while producing the output. A constructed model to measure the efficiency of neural networks with improved learning speed and classification accuracy is discussed. Hamid (2004) in his article talks about how to use business forecasting neural networks. The use of neural networks in finance is a promising field of research, particularly given the ready availability of large mass of data sets and the reported ability of neural networks to detect and assimilate relationships among a wide range of variables. Jardin (2008) explains that all the research being done in the last 20 years proves that neural networks is the best method to predict financial distress when the results are compared to other statistical tools. To improve the efficiency of the conventional methods, variables can be selected differently, as the results vary with the appropriate selection of variables. Cole, Sampson, and Zia (2009) performed a field experiment to check the relative importance of literacy and price, providing financial literacy education for randomly selected unbanked households, crossed by small rewards (ranging from US\$ 3 to US\$ 14) to open bank savings accounts. In Al-Shayea, Q.K., ElRefae, G.A. and El-Itter, S.F (2010), according to the authors, predicting financial distress on the basis of selected financial ratios shows the network's ability to learn trends that suit the bank's financial distress. Du Jardin (2010) explained the efficiency of neural networks in his paper using a set of variables to determine the financial distress. This paper says that the non-linear model is better than the linear model in the same way, that it says neural networks prove to be better in terms of predicting the financial health of the companies. López-de-Foronda and Pastor-Sanz (2000) provide a new paradigm for forecasting bank defaults a while before the 
bankruptcy takes place. The model is based on financial variables commonly used in the literature, but some changes are incorporated in the interpretation of variables and the approach is revised in line with the new business and economic conditions. Li and Ma (2011) in their paper surveyed the application of Artificial Neural Networks in forecasting financial market prices. The objective of this paper is to appraise the potential of using artificial neural networks to predict the financial system, as it is reflected in many relevant articles. Coelho and John (2011) talk about the stock of bankrupt firms listed on the NYSE, AMEX, and NASDAQ post-filing, whether they are correctly priced or not. Findings from this paper say that these stocks are traded by the retail investors. Murari (2012), in a study, obtained the results showing that the probability of bankruptcy of Indian banks' book value has decreased over the years, and the risk of bankruptcy of book value in the case of public sector banks is lower than in the case of private sector and foreign banks. Kasgari and Ebadi (2013), in their analysis, mention that the bankruptcy of manufacturing companies in the Tehran Stock Exchange Market was predicted using the artificial neural network. The technical regression was also used to interact with the neural network. Bredart (2014) used the technique of neural networks for predicting bankruptcy by a group of Belgian small and medium-sized enterprises. The paper addresses the performance of neural networks, as opposed to other models, and it provides 80 percent accurate results. Ghosh, Krishna, and Ramachandran (2016) in their analysis, mention how the PSU segment banks included in the established S\&P BSE Banks universe (i.e. SBI, BOB and PNB) were considered. Determining EPS with a high degree of accuracy will allow these banks to reliably attract FPI traffic, which in turn will support their regular cash inflow and thus ease their liquidity crunch. Two distinctly different approaches, such as Panel Data Regression (Econometric Method) and Artificial Neural Network (Machine Learning Tool), have in place a specific model with which the prediction of EPS could be quite accurate. Mansouri et al. (2016) aimed to concentrate on the contrast of the model of Artificial Neural Network and the model of Logistic Regression in the prediction of the bankruptcy of companies in Tehran Stock Exchange (TSE) in 3,2 and 1 year prior. Al-Hroot (2016) in his research aims to build a model of bankruptcy prediction with a more recent approach - 
neural networks for the Jordanian industrial sector. The results show that the final prediction model's accuracy rate is considered to be $100 \%$. Naidu and Govinda (2018) explains the advantage of Artificial Neural Networks as a machine learning tool over traditional statistical techniques, especially, when it comes to the prediction of bankruptcy which requires the back-propagation method to produce efficient results. Addo, Guegan and Hassani (2018) in their study, in predicting loan default probability, developed binary classifiers based on machine and deep learning models based on real data. The top 10 important features of these models are selected and then used by comparing their output on separate data in the modeling process to test the stability of binary classifiers. Kumar, Goel, Jain, and Singhal (2018) proposed an approach to incorporate a model of a neural network that will be used to predict the default loan. Taking into account the financial and personal details provided by the potential debtor, the prediction is carried out. Samek and Montavon (2018) in their tutorial, discussed two main ways to enhance the consistency of machine learning: describe the concepts learned from a model by constructing prototypes, and clarify the decisions of the model by defining the related input variables. Feng, Shaonan and Ling (2019) built a robust bankruptcy database of 11,827 U.S. public companies, showing that deep learning models provide superior predictive efficiency in predicting bankruptcy using textual disclosures. Selvamuthu, Kumar and Mishra (2019) compare the performance of three Neural Network learning algorithms, i.e., Levenberg-Marquardt, Scaled Conjugate Gradient and Bayesian Regularization by predicting over tick by tick dataset and 15-min dataset. The study shows that prediction using tick by tick data for the stock market gives much better results than prediction using 15-min dataset. Ghosh (2017) used GMM (Generalized System of Moments) and neural networks in his paper to predict the future EPS of India's 3 public sector banks by taking data from the past 12 years (2005-2014). Ohlson, Graham and Zmijewski scores are the metrics used by creditors to forecast bankruptcy. Results from this study show that the neural network helps to accurately predict banks' potential EPS. The same research group has quantified 'fear' based on this kind of credit fiasco and further identified its embedded link to the subtle behavioural traces 
in Indian markets as well. (Ghosh \& Srinivasan, 2014, 2015; Ghosh, Roux \& Ianole, 2017)

However, because of their prominence in the financial literature, many of those who have developed neural models have defined their final set of variables. Many research articles have used either a genetic algorithm or a method suitable for non-linear techniques to take into account the characteristics of neural networks. Thus, the significance of these experiments is reduced in each case, with only a few variables, small samples, and without attempting to compare several methods or criteria.

This study is to show that in many models used for bankruptcy, authors use variable selection methods without taking into account the very characteristics of the modeling techniques. Further, this paper looks at the research results of assessing the creditworthiness of a client. This research aimed to use the algorithm of backpropagation to simulate the credit decisions of a bank. Several network architectures are described here, designed and trained for randomly selected weights during several iterations. Numerical tests were done using the Neural Works as a statistical tool.

\section{Research Methodology}

The approach used in this study is to calculate the relation between different financial parameters such as EPS, GNPA, PAT, market capitalisation, etc. using historical data in post-occurrence form, i.e. using past data. Information and data were obtained from the companies' basic financial statements such as balance sheet, statement of profits, cash and other data published in the stock exchange by firms.

\section{Objective}

The objective of this study is to develop a bankruptcy prediction model for the private sector banks in India as a statistical tool for bankruptcy prediction in India.

1. Prediction of bankruptcy in Private sector Banks i.e. HDFC, ICICI, AXIS, YES Bank, Kotak Mahindra Bank, Federal Bank, Indusind Bank, RBL and Karur Vysya 
2. To check the efficacy of machine learning tools i.e. ANN (Artificial Neural Networks) in the prediction of bankruptcy

The sample has been made the same as the panel data regression in which every individual bank has been assigned a unique ID as the data collected is cross-sectional. The method which is implemented over this data set is Artificial Neural Networks. In the paper by Ghosh (2017), these multi-layer neural networks generally are shown to be very complex as they try to mimic human brain function. They act in a back-propagating fashion, so the prediction error is decreased at each level of learning by back-propagation.

The financial ratios which are being included in the data set to build the model are (collected for the time period from 2010 to 2019):

\section{Variables}

Dependent variable: $Y=$ EPS: Earning per Share

\section{Independent Variables}

1. PAT (Profit After Tax)

2. TA (Total Assets)

3. ROA (Return on Assets)

4. GNPA (Gross Non-Performing Assets)

5. PB (Price to Book ratio)

6. BV (Book Value)

7. PE (Price Earnings Ratio)

8. Market Capitalization

Other variables are Ohlson, Zmijewski, and Graham numbers, which will be the parameters to predict Bankruptcy.

The formula for calculating Ohlson's Score-

$\mathrm{O}=-1.32-0.407 \log (\mathrm{TA} / \mathrm{GNP})+6.03(\mathrm{TL} / \mathrm{TA})-1.43(\mathrm{WC} / \mathrm{TA})+$ $0.0757(\mathrm{CL} / \mathrm{CA})-1.72 \mathrm{X}-2.37(\mathrm{NI} / \mathrm{TA})-1.83(\mathrm{FFO} / \mathrm{TL})+0.285 \mathrm{Y}-$ $0.521\left(\mathrm{NI}_{\mathrm{T}}-\mathrm{NI}_{\mathrm{T}-1}\right) /\left(\left|\mathrm{NI}_{\mathrm{T}}\right|+\left|\mathrm{NI}_{\mathrm{T}-1}\right|\right)$

Where,

1. $\mathrm{GNP}=$ Gross National Product Price 
2. $\mathrm{TL}=$ Total Liabilities

3. $\mathrm{WC}=$ Working Capital

4. $\mathrm{CL}=$ Current Liabilities

5. $\mathrm{CA}=$ Current Assets

6. $\mathrm{X}=1$ if $\mathrm{TL}>\mathrm{TA}$, else 0

7. $\mathrm{NI}=$ Net Income

8. $\mathrm{FFO}=$ Funds from Operations

The formula for Zmijewski Score:

$Z=-4.336-4.513^{*}($ Net Income/Total Assets) $+5.679 *$ (Total Liabilities/Total Assets) $+0.004^{*}$ (Current Assets/Current Liabilities)

The formula for Graham's Number:

$G=(22.5 \text { * earnings per share * book value per share })^{1 / 2}$

As with any statistical model, it is necessary to estimate the parameters of a neural network model before using the network for predictive purposes. Training is called the process of determining these weights. A critical part of the use of neural networks is the training process. The network training is supervised for classification problems in that the network's desired or goal response for each input pattern is always identified as a priority.

\section{Data Analysis and Interpretation}

$\mathbf{H}_{0 \text { : }}$ This model can predict the bankruptcy for private sector banks in India

$\mathbf{H}_{1}$ : This model cannot predict the bankruptcy for private sector banks in India

The equation obtained from the results:

In the equation, $\mathrm{Y} 1=\mathrm{EPS}$ which is the dependent variable

$\mathrm{Y} 1=-0.000345972-\mathrm{N} 254^{*} 0.00950368+\mathrm{N} 254^{*} \mathrm{~N} 2 * 0.000297557+$ $\mathrm{N} 2 * 1.00955-\mathrm{N} 2 \wedge 2 * 0.000298231$ 
Ushus-Journal of Business Management, Vol. 19, No. 3 ISSN 0975-3311

$\mathrm{N} 2=-0.000149209-\mathrm{N} 861^{*} \mathrm{~N} 3 * 2.26676 \mathrm{e}-05+\mathrm{N} 861^{\wedge} 2^{*} 1.34282 \mathrm{e}-05+$ $\mathrm{N} 3 * 0.999944+\mathrm{N}^{\wedge}{ }^{\wedge} * 9.77374 \mathrm{e}-06$

$\mathrm{N} 3=0.00535231-\mathrm{N} 948^{*} 0.000834552+\mathrm{N}^{*} 48^{\wedge} 2^{*} 1.8024 \mathrm{e}-05+$ $\mathrm{N} 4 * 1.00015-\mathrm{N} 4{ }^{\wedge}{ }^{*} * 2.29414 \mathrm{e}-06$

$\mathrm{N} 4=1.26772 \mathrm{e}-06-\mathrm{N} 16^{*} 0.214336+\mathrm{N} 5 * 1.21434$

$\mathrm{N} 5=-0.00245844+\mathrm{N} 999 * 0.000224282+\mathrm{N} 6 * 0.999879+$ $\mathrm{N} 6{ }^{\wedge} 2 * 1.06951 \mathrm{e}-06$

$\mathrm{N} 6=-0.000308822-\mathrm{N} 574 * 0.00102847-\mathrm{N} 574{ }^{*} \mathrm{~N} 7{ }^{*} 0.00148971+$ $\mathrm{N} 574^{\wedge} 2 * 0.000747772+\mathrm{N}^{*} 1.00093+\mathrm{N} 7^{\wedge} 2^{*} 0.000743453$

$\mathrm{N} 7=-0.00134274-\mathrm{N} 174^{*} \mathrm{~N} 8^{*} 0.10495+\mathrm{N} 174^{\wedge} 2^{*} 0.0524599+$ $\mathrm{N} 8 * 1.00003+\mathrm{N}^{\wedge}{ }^{\wedge}{ }^{*} 0.0524898$

$\mathrm{N} 8=0.00200232+\mathrm{N} 415^{*} \mathrm{~N} 9 * 0.00681868-\mathrm{N} 415^{\wedge} 2^{*} 0.00337258+$ N9*0.999901 - N9^^2*0.00344479

$\mathrm{N} 9=-0.00264211-\mathrm{N} 240 * \mathrm{~N} 10^{*} 0.0921726+\mathrm{N} 240^{\wedge} 2^{*} 0.0461977+$ $\mathrm{N} 10^{*} 1.00007+\mathrm{N} 10^{\wedge} 2 * 0.0459742$

$\mathrm{N} 10=0.00017216-\mathrm{N} 973 * 0.000207902-\mathrm{N} 973^{*} \mathrm{~N} 11^{*} 1.54844 \mathrm{e}-05+$ N11*1.00057

$\mathrm{N} 11=4.94149 \mathrm{e}-06-\mathrm{N} 31 * 0.11335+\mathrm{N} 12 * 1.11335$

$\mathrm{N} 12=0.00294866+\mathrm{N} 414^{*} \mathrm{~N} 13^{*} 0.0139132-\mathrm{N} 414^{\wedge} 2^{*} 0.00695605+$ $\mathrm{N} 13^{*} 0.999926-\mathrm{N} 13^{\wedge} 2^{*} 0.00695638$

$\mathrm{N} 13=0.00482103$ - "GNPA, cubert"*0.000465547 + "GNPA, cubert $^{\prime \prime *} \mathrm{~N} 14^{*} 2.64804 \mathrm{e}-05+\mathrm{N} 14^{*} 0.999854-\mathrm{N} 14^{\wedge} 2 * 4.47322 \mathrm{e}-06$

$\mathrm{N} 14=-4.15691 \mathrm{e}-06+\mathrm{N} 23 * 0.139453+\mathrm{N} 15^{*} 0.860547$

$\mathrm{N} 15=0.00208246-\mathrm{N} 396 * 0.0107527+\mathrm{N} 396 * \mathrm{~N} 16 * 0.0401151-$ $\mathrm{N} 396^{\wedge} 2 * 0.0199856+\mathrm{N} 16^{*} 1.01074-\mathrm{N} 16^{\wedge} 2 * 0.0201282$

$\mathrm{N} 23=-0.0086738+\mathrm{N} 537 * 0.00133365-\mathrm{N} 537 * \mathrm{~N} 24^{*} 0.0145815+$ $\mathrm{N} 537^{\wedge} 2 * 0.00724962+\mathrm{N} 24^{*} 0.998442+\mathrm{N} 24^{\wedge} 2^{*} 0.00733532$

$\mathrm{N} 24=-0.0206173+\mathrm{N} 293 * 0.0374003-\mathrm{N} 293 * \mathrm{~N} 36^{*} 0.591194+$ $\mathrm{N} 293^{\wedge} 2 * 0.293717+\mathrm{N} 36^{*} 0.962315+\mathrm{N} 36^{\wedge} 2 * 0.297487$

$\mathrm{N} 36=-0.00973435+\mathrm{N} 54 * 0.501401-\mathrm{N} 54 * \mathrm{~N} 62 * 3.96553+$ $\mathrm{N} 54^{\wedge} 2^{*} 1.97967+\mathrm{N} 62^{*} 0.498364+\mathrm{N} 62^{\wedge} 2^{*} 1.98587$ 
$\mathrm{N} 62=0.0325927-\mathrm{N} 348^{*} 0.329673+\mathrm{N} 348^{*} \mathrm{~N} 85^{*} 0.600892-$ $\mathrm{N} 348^{\wedge} 2^{*} 0.297924+\mathrm{N} 85^{*} 1.32925-\mathrm{N} 85^{\wedge} 2^{*} 0.302962$

$\mathrm{N} 348=-0.016558+\mathrm{N} 505^{*} 1.14855-\mathrm{N} 505^{*} \mathrm{~N} 629 * 0.00512448-$ $\mathrm{N} 629^{*} 0.147381+\mathrm{N}^{2} 2^{\wedge} 2^{*} 0.0051175$

$\mathrm{N} 54=0.051543+\mathrm{N} 137^{*} 0.996432+\mathrm{N} 137^{*} \mathrm{~N} 142 * 2.95655-$ $\mathrm{N} 137^{\wedge} 2^{*} 1.49132-\mathrm{N} 142^{\wedge} 2^{*} 1.46518$

$\mathrm{N} 137=-0.0402705-\mathrm{N} 531^{*} 0.195667-\mathrm{N} 531^{*} \mathrm{~N} 151 * 0.0567498+$ $\mathrm{N} 531^{\wedge} 2 * 0.0301244+\mathrm{N} 151^{*} 1.19776+\mathrm{N}^{*} 51^{\wedge} 2 * 0.0266045$

$\mathrm{N} 151=0.130454+\mathrm{N} 274 * 0.993166+\mathrm{N} 274 * \mathrm{~N} 370 * 0.570482-$ $\mathrm{N} 274^{\wedge} 2 * 0.281317-\mathrm{N} 370^{\wedge} 2 * 0.289079$

$\mathrm{N} 370=-0.231734+\mathrm{N} 491 * 0.784821+\mathrm{N} 491^{*} \mathrm{~N} 575 * 0.00464012-$ $\mathrm{N} 491^{\wedge} 2 * 0.00499674+\mathrm{N} 575 * 0.240605$

$\mathrm{N} 575=-0.0730267+\mathrm{N} 621^{*} 1.71315-\mathrm{N} 621 * \mathrm{~N} 890 * 0.0485461+$

$\mathrm{N} 621^{\wedge} 2 * 0.0221532-\mathrm{N} 890 * 0.504145+\mathrm{N} 890^{\wedge} 2^{*} 0.0165896$

$\mathrm{N} 491=2.57073+\mathrm{N} 622 * 1.53698-\mathrm{N} 622^{*} \mathrm{~N} 897^{*} 0.0457667+$ $\mathrm{N} 622^{\wedge} 2^{*} 0.0238219-\mathrm{N} 897^{*} 0.660094+\mathrm{N} 897^{\wedge} 2^{*} 0.0185833$

$\mathrm{N} 293=-0.0432651+\mathrm{N} 310 * 0.718299+\mathrm{N} 310 * \mathrm{~N} 516 * 0.354189-$ $\mathrm{N} 310^{\wedge} 2 * 0.166005+\mathrm{N} 516^{*} 0.297319-\mathrm{N} 516^{\wedge} 2 * 0.188437$

$\mathrm{N} 516=-0.3677+\mathrm{N} 634 * 1.68475-\mathrm{N} 634^{*} \mathrm{~N} 890 * 0.0470133+$ $\mathrm{N} 634^{\wedge} 2^{*} 0.0219401-\mathrm{N} 890^{*} 0.426872+\mathrm{N} 890^{\wedge} 2^{*} 0.0141928$

N634 = 21.1971 - GNPA^2*7.5496e-12 - "GRHM, cubert"*11.105 + "GRHM, cubert"^2*1.6956

$\mathrm{N} 310=0.0711427+\mathrm{N} 487^{*} 0.324977+\mathrm{N} 487^{\wedge} 2^{*} 0.000153679+$ $\mathrm{N} 505 * 0.665896$

$\mathrm{N} 537=0.0494061+\mathrm{N} 579 * 1.40474-\mathrm{N} 607 * 0.407523$

$\mathrm{N} 579=-0.834652+\mathrm{N} 616^{*} 1.21838+\mathrm{N} 616^{*} \mathrm{~N} 690 * 0.0733063-$ $\mathrm{N} 616^{\wedge} 2 * 0.0316538-\mathrm{N} 690^{\wedge} 2^{*} 0.046078$

$\mathrm{N} 690=11.4516-\mathrm{ROA}^{*} 21.1045+\mathrm{ROA}^{*} \mathrm{BV}^{*} 0.0978686+$ $\mathrm{ROA}^{\wedge} 2 * 8.26706-\mathrm{BV}^{\wedge} 2 * 0.000105619$

N616 = -1947.85 + "GRHM, cubert"*1215.73 - "GRHM, cubert"*"Zmijewski, cubert"*570.228 + "GRHM, cubert"^2*1.63123 + "Zmijewski, cubert"^2*425.697 
$\mathrm{N} 414=0.280103+\mathrm{N} 928^{\star} \mathrm{N} 496^{*} 0.00340343-\mathrm{N} 928^{\wedge} 2^{*} 0.00341071+$ $\mathrm{N} 496^{*} 1.00759-\mathrm{N} 496^{\wedge} 2^{*} 0.000721009$

$\mathrm{N} 496=0.327312+\mathrm{N} 624 * 1.76324-\mathrm{N} 624 * \mathrm{~N} 890 * 0.0490482+$ $\mathrm{N} 624^{\wedge} 2 * 0.0220131-\mathrm{N} 890^{*} 0.581132+\mathrm{N} 890^{\wedge} 2^{*} 0.0175898$

$\mathrm{N} 928=7.06022+\mathrm{PE}^{*} 0.530565-\mathrm{PE}^{\wedge} 2^{*} 0.00108938-$ "PAT, cubert"*1.87086 + "PAT, cubert"^2*0.124952

$\mathrm{N} 973=-31.8425+\mathrm{PE}^{*} 0.715549-\mathrm{PE}^{\wedge} 2^{*} 0.0014188+$ "ROA, cubert"^2*29.6584

$\mathrm{N} 240=0.0127224-\mathrm{N} 594 * 0.0754075+\mathrm{N} 280 * 1.07469$

$\mathrm{N} 594=-0.460747+\mathrm{N} 630 * 1.1212+\mathrm{N} 630 * \mathrm{~N} 700 * 0.0728307-$ $\mathrm{N} 630^{\wedge} 2 * 0.0342801+\mathrm{N} 700^{*} 0.0264364-\mathrm{N} 700^{\wedge} 2^{*} 0.0405829$

$\mathrm{N} 700=36.3758-\mathrm{ROA}^{*} 27.4477+\mathrm{ROA} * " \mathrm{BV}$, cubert"*8.01749 - "BV, cubert $^{\prime \prime *} 12.6083+$ "BV, cubert"^2*0.948408

$\mathrm{N} 174=0.0490027+\mathrm{N} 285^{*} 0.718113+\mathrm{N} 285^{*} \mathrm{~N} 458^{*} 0.329829-$ $\mathrm{N} 285^{\wedge}{ }^{*} 0.159726+\mathrm{N} 458^{*} 0.280831-\mathrm{N} 458^{\wedge} 2 * 0.170088$

$\mathrm{N} 458=-0.145064+\mathrm{N} 518^{*} 0.887696-\mathrm{N} 518^{*} \mathrm{~N} 586^{*} 0.190732+$ $\mathrm{N} 518^{\wedge} 2^{*} 0.0944105+\mathrm{N} 586^{*} 0.0997785+\mathrm{N} 586^{\wedge} 2^{*} 0.0964868$

$\mathrm{N} 586=-0.506294+\mathrm{N} 623^{*} 1.23152-\mathrm{N} 623^{*} \mathrm{~N} 887^{*} 0.0248905+$ $\mathrm{N} 623^{\wedge} 2 * 0.0155961$

$\mathrm{N} 887=-10.9804+$ "GNPA, cubert"*0.396784 - "GNPA, cubert $^{\prime \wedge} 2 * 0.00588583+$ "BV, cubert"^2*0.939395

N623 = 26.2454 + TA*"GRHM, cubert"*3.12108e-06 - TA^2*2.06082e-

11 - "GRHM, cubert"*12.5409 + "GRHM, cubert"^2*1.71274

$\mathrm{N} 518=-0.0565621+\mathrm{N} 621^{*} 1.81547-\mathrm{N} 621^{*} \mathrm{~N} 896^{*} 0.0546183+$ $\mathrm{N} 621^{\wedge} 2^{*} 0.02404-\mathrm{N} 896^{*} 0.589596+\mathrm{N} 896^{\wedge} 2^{*} 0.0199437$

$\mathrm{N} 285=0.0256008+\mathrm{N} 629^{*} 0.0932052-\mathrm{N} 629^{*} \mathrm{~N} 396^{*} 0.0143061+$ $\mathrm{N} 629^{\wedge} 2^{*} 0.0036231+\mathrm{N} 396^{*} 0.893634+\mathrm{N} 396^{\wedge} 2^{*} 0.0108072$

$\mathrm{N} 574=-0.500915+\mathrm{N} 631^{*} 1.56938-\mathrm{N} 631^{*} \mathrm{~N} 890^{*} 0.0393727+$ $\mathrm{N} 631^{\wedge} 2 * 0.0190676-\mathrm{N} 890^{*} 0.310778+\mathrm{N} 890^{\wedge} 2^{*} 0.00986262$

$\mathrm{N} 631=22.8333-\mathrm{PB}^{*} 0.12396+\mathrm{PB}^{* \prime \prime} \mathrm{GRHM}$, cubert ${ }^{\prime \prime *} 0.0946093-$ "GRHM, cubert"*11.6595 + "GRHM, cubert"^2*1.7 
N999 $=-3.35486+$ "GNPA, cubert"*0.827611 - "GNPA, cubert"^2*0.0112478+ "PB, cubert"^2*6.91929

$\mathrm{N} 16=-0.00289255-\mathrm{N} 68^{*} \mathrm{~N} 17^{*} 2.28444+\mathrm{N}^{*} 8^{\wedge} 2^{*} 1.14097+\mathrm{N} 17^{*} 0.9998$ $+\mathrm{N} 17^{\wedge} 2^{*} 1.14348$

$\mathrm{N} 17=-0.000170988-\mathrm{N} 570 * 0.0118077-\mathrm{N} 570 * \mathrm{~N} 18 * 0.006066+$ $\mathrm{N} 570^{\wedge} 2 * 0.00319287+\mathrm{N} 18^{*} 1.0113+\mathrm{N} 18^{\wedge} 2^{*} 0.00287982$

$\mathrm{N} 18=-0.00079274-\mathrm{N} 1007^{*} 0.00116681+\mathrm{N} 1007^{\wedge} 2^{*} 7.29619 \mathrm{e}-05+$ N20*0.999614

$\mathrm{N} 20=-0.00686411-\mathrm{N} 317^{*} \mathrm{~N} 31^{*} 0.272441+\mathrm{N} 317^{\wedge} 2^{*} 0.13622+$ $\mathrm{N} 31^{*} 0.999205+\mathrm{N} 31^{\wedge} 2 * 0.136231$

$\mathrm{N} 31=0.0174895-\mathrm{N} 231 * 0.0936679+\mathrm{N} 231 * \mathrm{~N} 33 * 0.739282-$ $\mathrm{N} 231^{\wedge} 2^{*} 0.369591+\mathrm{N} 33^{*} 1.09329-\mathrm{N} 33^{\wedge} 2^{*} 0.369689$

$\mathrm{N} 33=-0.0150717-\mathrm{N} 171 * 0.561878-\mathrm{N} 171 * \mathrm{~N} 53 * 1.42392+$ $\mathrm{N} 171^{\wedge} 2 * 0.719706+\mathrm{N} 53^{*} 1.56283+\mathrm{N} 53^{\wedge} 2^{*} 0.7042$

$\mathrm{N} 53=0.0104758+\mathrm{N} 101 * 0.667506+\mathrm{N} 101 * \mathrm{~N} 142 * 0.0127645-$ $\mathrm{N} 101^{\wedge} 2 * 0.0127453+\mathrm{N} 142 * 0.33127$

$\mathrm{N} 142=-0.00459707-\mathrm{N} 282 * 1.09786-\mathrm{N} 282 * \mathrm{~N} 160 * 0.273573+$ $\mathrm{N} 282^{\wedge} 2 * 0.15365+\mathrm{N} 160 * 2.09816+\mathrm{N} 160^{\wedge} 2 * 0.119915$

$\mathrm{N} 160=0.0820746+\mathrm{N} 279 * 0.992457+\mathrm{N} 279 * \mathrm{~N} 281 * 0.941045-$ $\mathrm{N} 279^{\wedge} 2 * 0.494166-\mathrm{N} 281^{\wedge} 2 * 0.446747$

$\mathrm{N} 279=-0.00634514+\mathrm{N} 396 * 0.56492+\mathrm{N} 499 * 0.435437$

$\mathrm{N} 282=-0.00683996+\mathrm{N} 339 * 0.433556+\mathrm{N} 339 * \mathrm{~N} 396 * 0.00389835+$ $\mathrm{N} 396 * 0.567051-\mathrm{N} 396^{\wedge} 2^{*} 0.00390417$

$\mathrm{N} 101=0.0231221-\mathrm{N} 531 * 0.127483-\mathrm{N} 531 * \mathrm{~N} 158 * 0.00358138+$ N531^2*0.00368053 + N158*1.12289

$\mathrm{N} 158=0.0493769+\mathrm{N} 263^{*} \mathrm{~N} 273^{*} 0.674085-\mathrm{N} 263^{\wedge} 2^{*} 0.33187+$ $\mathrm{N} 273^{*} 0.999402-\mathrm{N} 273^{\wedge} 2^{*} 0.342219$

$\mathrm{N} 273=0.0840559+\mathrm{N} 621^{*} 0.0859298-\mathrm{N} 621^{*} \mathrm{~N} 396^{*} 0.0145692+$ $\mathrm{N} 621^{\wedge} 2 * 0.00391133+\mathrm{N} 396^{*} 0.895132+\mathrm{N} 396^{\wedge} 2^{*} 0.0108562$

$\mathrm{N} 263=-0.0276454+\mathrm{N} 339 * 1.06491-\mathrm{N} 339 * \mathrm{~N} 608 * 0.109059+$ $\mathrm{N} 339^{\wedge} 2 * 0.0550751-\mathrm{N} 608^{*} 0.0826146+\mathrm{N}^{*} 08^{\wedge} 2^{*} 0.0541257$ 
$\mathrm{N} 339=-0.07489+\mathrm{N} 505^{*} 1.1545-\mathrm{N} 505^{*} \mathrm{~N} 620^{*} 0.00529697-$ $\mathrm{N} 620^{*} 0.147298+\mathrm{N} 620^{\wedge} 2^{*} 0.00520578$

$\mathrm{N} 171=-0.0278677+\mathrm{N} 294 * 0.464265+\mathrm{N} 294^{*} \mathrm{~N} 317^{*} 0.0167775+$ $\mathrm{N} 317^{*} 0.539087$ - N317^2*0.0168291

$\mathrm{N} 294=0.102455-\mathrm{N} 624^{*} \mathrm{~N} 396^{*} 0.019193+\mathrm{N} 624^{\wedge} 2^{*} 0.00742123+$ $\mathrm{N} 396^{*} 0.977767+\mathrm{N} 396^{\wedge} 2^{*} 0.0120157$

N624 = -2.44362 + GRHM*0.0816428 + "GNPA, cubert"*0.087313 "GNPA, cubert"^2*0.00131782

$\mathrm{N} 231=0.016853-\mathrm{N} 607 * 0.0693669+\mathrm{N} 280^{*} 1.06842$

$\mathrm{N} 280=-16.5908+$ "GRHM, cubert"*6.41856 - "GRHM, cubert"*N531*0.0347839 - "GRHM, cubert"^2*0.548788 + N531*0.980367 + N531^²*0.00652445

$\mathrm{N} 531=51.9744-$ "GRHM, cubert"*28.4203 - "GRHM, cubert"*N896*0.378317 + "GRHM, cubert"^2*4.25347 + $\mathrm{N} 896^{*} 0.89579+\mathrm{N} 896^{\wedge} 2^{*} 0.0151779$

$\mathrm{N} 896=-8.76848+$ "BV, cubert"^2*0.981567

$\mathrm{N} 607=-0.44766+\mathrm{N} 635^{*} 1.01628+\mathrm{N} 635^{*} \mathrm{~N} 836^{*} 0.0587269-$ $\mathrm{N} 635^{\wedge} 2^{*} 0.0280668+\mathrm{N} 836^{*} 0.0901698-\mathrm{N} 836^{\wedge} 2^{*} 0.0313428$

$\mathrm{N} 836=-7024.78+$ "BV, cubert"*4402.99 - "BV, cubert"*"Zmijewski,

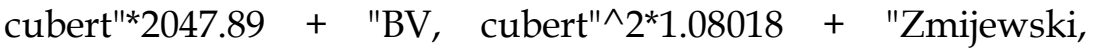
cubert"^2*1518.07

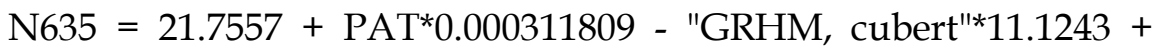
"GRHM, cubert"^2*1.64832

$\mathrm{N} 317=0.060068-\mathrm{N} 415^{*} \mathrm{~N} 506^{*} 0.0183589+\mathrm{N} 415^{\wedge} 2^{*} 0.0185118+$ $\mathrm{N} 506 * 0.991425$

$\mathrm{N} 506=2.96058+\mathrm{N} 627^{*} 1.59055-\mathrm{N} 627^{*} \mathrm{~N} 897^{*} 0.0496961+$ $\mathrm{N} 627^{\wedge} 2^{*} 0.0254112-\mathrm{N} 897^{*} 0.751213+\mathrm{N} 897^{\wedge} 2^{*} 0.0213691$

$\mathrm{N} 897=0.343761+\mathrm{BV}^{*} 0.113867$

$\mathrm{N} 627=-1.90035+\mathrm{GRHM}^{*} 0.0823892$

$\mathrm{N} 415=-0.333854+\mathrm{N} 581^{*} 0.918928-\mathrm{N} 581 * \mathrm{~N} 890^{*} 0.0111591+$ $\mathrm{N} 581^{\wedge} 2 * 0.00832481+\mathrm{N} 890 * 0.130965$

$\mathrm{N} 890=-8.47262-\mathrm{GNPA}^{\wedge} 2 * 2.8315 \mathrm{e}-11+$ "BV, cubert"^2*0.982361 
$\mathrm{N} 581=42.0941-\mathrm{BV}^{*}$ "GRHM, cubert"*0.0216686 + BV^2*0.000139011

- "GRHM, cubert"*21.7335 + "GRHM, cubert"^2*3.31022

$\mathrm{N} 1007=-1.57786+\mathrm{PE}^{*} 0.710394-\mathrm{PE}^{\wedge} 2 * 0.00149539+$ "GNPA, cubert"*0.845136 - "GNPA, cubert"^2*0.0125065

$\mathrm{N} 570=-0.290561+\mathrm{N} 600 * 1.05157+\mathrm{N} 600 * \mathrm{~N} 687^{*} 0.0361634-$

$\mathrm{N} 600^{\wedge} 2 * 0.0170482-\mathrm{N}^{*} 87^{\wedge} 2 * 0.0188099$

$\mathrm{N} 687=1.91015+\mathrm{N} 859 * 0.393852+\mathrm{N} 859 * \mathrm{~N} 992 * 0.0256023$

N992 = -20.8016 - GNPA*"ROA, cubert"*3.11809e-05 +

GNPA^2*6.7441e-11 + "ROA, cubert"^2*31.6247

$\mathrm{N} 859=-1.42436+\mathrm{TA}^{*} \mathrm{BV}^{*} 2.12552 \mathrm{e}-07-\mathrm{TA}^{\wedge} 2 * 4.63752 \mathrm{e}-11+$ $\mathrm{BV}^{*} 0.145385-\mathrm{BV}^{\wedge} 2^{*} 0.000236524$

$\mathrm{N} 600=0.449089+\mathrm{N} 625^{*} 1.05935-\mathrm{N} 625^{*} \mathrm{~N} 826^{*} 0.0233017+$ $\mathrm{N} 625^{\wedge} 2 * 0.0184407$

$\mathrm{N} 826=1.68731$ - "TA, cubert"*0.398409 + "TA, cubert"*"BV, cubert"*0.164586 - "TA, cubert"^2*0.00304268

$\mathrm{N} 68=-0.000148967+\mathrm{N} 85 * 0.448237+\mathrm{N} 90 * 0.551771$

$\mathrm{N} 90=0.0397049-\mathrm{N} 347^{*} 0.152806+\mathrm{N} 347^{*} \mathrm{~N} 149 * 0.405799-$ $\mathrm{N} 347^{\wedge} 2 * 0.205315+\mathrm{N} 149 * 1.15048-\mathrm{N} 149^{\wedge}{ }^{*} * 0.200451$

$\mathrm{N} 149=0.0503839+\mathrm{N} 272 * 0.187747+\mathrm{N} 272 * \mathrm{~N} 274 * 0.576964-$

$\mathrm{N} 272^{\wedge} 2^{*} 0.287211+\mathrm{N} 274^{*} 0.810851-\mathrm{N} 274^{\wedge} 2^{*} 0.289742$

$\mathrm{N} 274=0.0831922+\mathrm{N} 620 * 0.0839064-\mathrm{N} 620 * \mathrm{~N} 396 * 0.0147273+$

$\mathrm{N} 620^{\wedge} 2 * 0.00401783+\mathrm{N} 396^{*} 0.896971+\mathrm{N} 396^{\wedge} 2 * 0.0109134$

N620 = -1.51727 + GRHM*0.0826055 - "PE, cubert"^2*0.0511598

$\mathrm{N} 272=0.00430176+\mathrm{N} 346 * 1.08194-\mathrm{N} 346^{*} \mathrm{~N} 608 * 0.105056+$

$\mathrm{N} 346^{\wedge} 2^{*} 0.0525434-\mathrm{N} 608^{*} 0.101542+\mathrm{N}^{*} 08^{\wedge} 2^{*} 0.0526697$

$\mathrm{N} 347=-0.056841-\mathrm{N} 630 * 0.154276-\mathrm{N} 630 * \mathrm{~N} 499 * 0.00536938+$

$\mathrm{N} 630^{\wedge} 2 * 0.00527217+\mathrm{N} 499 * 1.16068$

$\mathrm{N} 499=2.88781+\mathrm{N} 622 * 1.59048-\mathrm{N} 622 * \mathrm{~N} 895 * 0.0494308+$ $\mathrm{N} 622^{\wedge} 2^{*} 0.0253417-\mathrm{N} 895^{*} 0.745352+\mathrm{N} 895^{\wedge} 2^{*} 0.0211353$

$\mathrm{N} 895=0.589643-\mathrm{GNPA}^{\wedge} 2 * 2.00639 \mathrm{e}-11+\mathrm{BV}^{*} 0.113729$

N622 = -1.76772 - GNPA^²*9.87853e-12 + GRHM*0.0822971 
$\mathrm{N} 85=-0.00841068-\mathrm{N} 487^{*} 0.187717+\mathrm{N} 487^{*} \mathrm{~N} 170^{*} 0.00486142+$ $\mathrm{N} 170 * 1.18726-\mathrm{N} 170^{\wedge} 2^{*} 0.00482991$

$\mathrm{N} 170=0.0258822+\mathrm{N} 260 * 0.655028+\mathrm{N} 260 * \mathrm{~N} 281 * 0.0146661-$ $\mathrm{N} 260^{\wedge} 2 * 0.0146181+\mathrm{N} 281 * 0.341965$

$\mathrm{N} 281=0.0715416-\mathrm{GRHM}^{*} \mathrm{~N} 396^{*} 0.00150342+\mathrm{GRHM}^{\wedge} 2^{*} 4.47806 \mathrm{e}-$ $05+\mathrm{N} 396^{*} 0.988048+\mathrm{N} 396^{\wedge} 2^{*} 0.011884$

$\mathrm{N} 396=-9.82209+$ "BV, cubert"*4.2599 - "BV, cubert"^2*0.398298 + $\mathrm{N} 487^{*} 0.878923+\mathrm{N} 487^{\wedge} 2^{*} 0.00207357$

$\mathrm{N} 260=-0.0278465+\mathrm{N} 337^{*} 1.06483-\mathrm{N} 337^{*} \mathrm{~N} 608^{*} 0.10916+$ $\mathrm{N} 337^{\wedge} 2^{*} 0.0551302-\mathrm{N} 608^{*} 0.0825544+\mathrm{N} 608^{\wedge} 2^{*} 0.0541727$

$\mathrm{N} 608=1.81907+\mathrm{N} 625^{*} 0.851116+\mathrm{N} 625^{\wedge} 2^{*} 0.00871908-$ $\mathrm{N} 833^{\wedge} 2 * 0.00830093$

$\mathrm{N} 833=-2.24446+\mathrm{BV}^{* 1 " T A}$, cubert"* $0.00146275+$ "TA, cubert" ${ }^{\prime *} 0.306774$ - "TA, cubert" ${ }^{\prime \prime}{ }^{*} 0.00329381$

$\mathrm{N} 625=-1.91694+\mathrm{PAT}^{*} 0.000271559+\mathrm{GRHM}^{*} 0.078174$

$\mathrm{N} 337=-0.0775478+\mathrm{N} 505^{*} 1.15621-\mathrm{N} 505^{*} \mathrm{~N} 621 * 0.00534456-$

$\mathrm{N} 621^{*} 0.148843+\mathrm{N} 621^{\wedge} 2 * 0.00525291$

$\mathrm{N} 621=-1.69276-\mathrm{PE}^{*} 0.00634885+\mathrm{GRHM}{ }^{*} 0.0824184$

$\mathrm{N} 948=13.2235+\mathrm{N}^{\circ}{ }^{*} \mathrm{~N} 994 * 2.63979-\mathrm{N}^{*} 8^{\wedge} 2^{*} 1.36391-$ N994*1.48523 - N994^2*1.18853

$\mathrm{N} 994=5.46343 \mathrm{e}+06+$ "PE, cubert"*"Zmijewski, cubert"*0.748904 "Zmijewski, cubert"*5.07077e+06 + "Zmijewski, cubert"^2*1.17658e+06

$\mathrm{N} 986=962686-Z^{2}$ ijewski*192770 + Zmijewski^2*9650.13 + "PB, cubert $^{\prime \prime} 2 * 2.30747$

N861 = 5.00355 - "GNPA, cubert"*"""M Cap", cubert"*0.0337205 + "GNPA, cubert"^2*0.0186877 + "'M Cap", cubert"^2*0.0170316

$\mathrm{N} 254=-0.147238+\mathrm{N} 291 * 1.00457-\mathrm{N} 291 * \mathrm{~N} 540 * 0.183383+$ $\mathrm{N} 291^{\wedge} 2 * 0.0936692+\mathrm{N} 540^{\wedge} 2 * 0.0896224$

$\mathrm{N} 540=-1.58128+\mathrm{N} 588^{*} 0.884734+\mathrm{N} 588^{\wedge} 2^{*} 0.000944588+$ $\mathrm{N} 949^{*} 0.233676-\mathrm{N} 949^{\wedge} 2^{*} 0.00246759$

$\mathrm{N} 949=2.94599-\mathrm{N} 988^{*} 0.596803+\mathrm{N} 988^{*} \mathrm{~N} 1008^{*} 0.0724217$ 
N1008 = -5.47956 + "GNPA, cubert"*1.78802 - "GNPA, cubert"*"PE, cubert $^{\prime \prime *} 0.294622$ - "GNPA, cubert"^2*0.0137906 + "PE, cubert ${ }^{\prime \prime *} 5.82153$

$\mathrm{N} 988=6.0901 \mathrm{e}+06+$ "PB, cubert"^2*2.72043 - "Zmijewski, cubert"*5.65425e+06 + "Zmijewski, cubert"^2*1.3124e+06

$\mathrm{N} 588=0.780532+\mathrm{N} 629 * 1.27911-\mathrm{N} 629 * \mathrm{~N} 889 * 0.0294607+$ $\mathrm{N} 629^{\wedge} 2 * 0.0179257-\mathrm{N} 889^{*} 0.241588+\mathrm{N} 889^{\wedge} 2^{*} 0.00645325$

N889 = -2.54953 + BV*0.108776 + "GNPA, cubert"*0.406219 - "GNPA, cubert" ${ }^{\prime \wedge} 2 * 0.00568902$

$$
\begin{aligned}
& \mathrm{N} 291=-0.00503351+\mathrm{N} 346^{*} 0.573563+\mathrm{N} 400^{*} 0.426721 \\
& \mathrm{~N} 400=0.413838+\mathrm{N} 487^{*} 0.682425+\mathrm{N} 487^{\wedge} 2 * 0.00768647+ \\
& \mathrm{N} 629 * 0.26068-\mathrm{N} 629^{\wedge} 2^{*} 0.00681697
\end{aligned}
$$

N629 = 21.9125 - PE*0.00624743 - "GRHM, cubert"*11.3106 + "GRHM, cubert"^2*1.71238

$\mathrm{N} 487=21.0328$ - "BV, cubert"*"GRHM, cubert"*4.83736 + "BV, cubert"^2*1.90578 - "GRHM, cubert"*10.151 + "GRHM, cubert"^2*4.28045

\section{$\mathrm{N} 346=-0.0641058+\mathrm{N} 505 * 1.15569-\mathrm{N} 505 * \mathrm{~N} 630 * 0.00529191-$ $\mathrm{N} 630 * 0.148596+\mathrm{N} 630^{\wedge} 2 * 0.00518591$}

$\mathrm{N} 630=22.6948$ - "TA, cubert"*0.0554821 + "TA, cubert"*"GRHM, cubert"*0.0477962 - "TA, cubert"^2*0.00172812 - "GRHM, cubert"*10.9541 + "GRHM, cubert"^2*1.42722

\section{$\mathrm{N} 505=-0.193502-\mathrm{BV}^{*} 0.0731115-\mathrm{BV}^{*} \mathrm{GRHM}{ }^{*} 0.000466217+$} $\mathrm{BV}^{\wedge} 2^{*} 0.000277063+\mathrm{GRHM}^{*} 0.121679+\mathrm{GRHM}^{\wedge} 2 * 0.000172491$

Here, the model is developed to predict the bankruptcy in the private sector banks in India using neural networks because this method is based on ack Propagation, which means that when input travels to the output, it sends back the signal to improve the model further so that the model will have less number of errors. Neural networks divide the data into two parts i.e. training set (75\%) and test set (25\%) (see annexures for reference); it shows the fitness of model with respect to the blue part of data which is the training set, the red part is the residuals set (test) which shows the values differing in the actual and predicted values. The output gives the 
same values for actual and predicted, which means the residuals are zero for all observations and this model is highly robust and $100 \%$ accurate (annexures). The number of perceptrons impacting the model is more than 500, making the model robust and sustainable as cognitive dissonance could be present. Cognitive dissonance refers to a situation that involves attitudes, values or habits that conflict. The cardinal equation generated from the model shows that none of the variables has a direct link to the output. However, they have an indirect link through several neural networks, as more than 500 nodes are sending Back-Propagation signals to rectify the errors in the model which work on the sigmoid functions in reply to almost 1000 nodes, that auto-correct the error and send the feed-forward signal to the output.

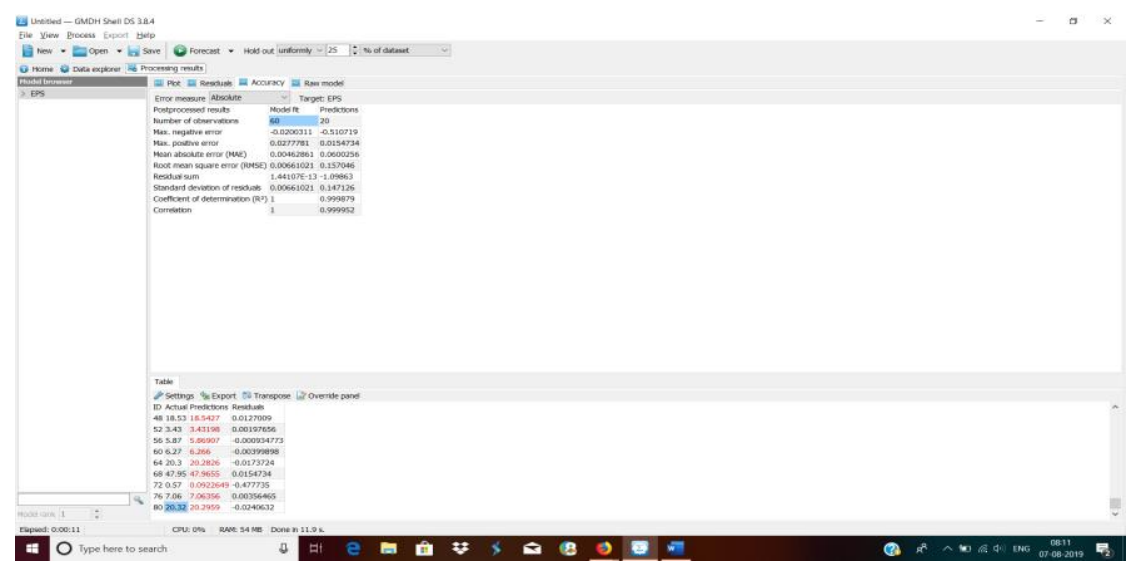

Fig 2: Results from the model

From the results, it can be said that the financial ratios included are the predictor of bankruptcy though the strong predictors namely, Ohlson's Score, Zmijewski and Graham's Number. The authors also accept the null hypothesis, as the value of RMSE is nearly zero which means the model is highly robust. The coefficient of determination says the model is linear giving the value equal to 1 . Here, one can say that the residuals are static and the standard deviation is zero between the predicted and actual values. In layman's words, one can say that the model is extremely good, as neural networks algorithms can't differentiate between marginal predictions. The variables which are impacting the prediction of Bankruptcy are the GNPA, ROA and Graham's Number. A minor impact is shown by the 
Zmijewski number though these variables don't have a direct link, as approximately 1000 behavioral layers are there between these independent variables and the financial parameters of every bank. Overall, this model is extremely robust and can be used for the bankruptcy predictions in the Indian banks.

\section{Conclusion}

In many recent studies of bankruptcy prediction, the application of neural networks has been reported. The role of neural networks, however, is not well known in predicting bankruptcy or general classification. Without a clear understanding of how neural networks function, the full potential of this methodology will be difficult to harvest. The neural network has proved to be more stable on reduced sample sizes than the discriminating method of analysis. This paper seeks to bridge the gap between ANN's theoretical growth and real-world implementations. From the variables' perspective, Ohlson's score and Graham's number are proved to be strong when compared with the other variables in the prediction of bankruptcy. The results obtained show that the model is highly robust and can predict the bankruptcy.

\section{Findings}

1. The research is quantitative as it has been done over the financial parameters. It doesn't take into account the parameters of behavioural finance.

2. Several studies have already been done on the bankruptcy prediction, using different models such as MultiDiscriminant Analysis, Altman Z-score but Artificial Neural Networks prove to be better in the prediction of bankruptcy over those models. The result obtained shows that the model is highly accurate.

3. More work in this field should be carried out using different ratios to see if the precision of the forecast can be improved.

4. There are some limitations to this report as this study was performed in a given country. A similar model could be evaluated in different countries to reinforce our conclusions. 


\section{References}

Addo, P. M., Guegan, D., \& Hassani, B. (2018). Credit risk analysis using machine and deep learning models. Risks, 6(2), 38.

Al-hroot, Y. A. K. (2016). Bankruptcy prediction using multilayer perceptron neural networks in Jordan. European Scientific Journal, 12(4).

Al-shayea, Q. K., El-refae, G. A., \& El-itter, S. F. (2010). Neural networks in bank insolvency prediction. IJCSNS International Journal of Computer Science and Network Security, 10(5), 240-245.

Bansal, R., \& Mohanty, A. (2013). A Study on financial performance of commercial banks in India: Application of Camel model. Al-Barkaat Journal of Finance $\mathcal{E}$ Management, 5(2), 60-79.

Begley, J., Ming, J., \& Watts, S. (1996). Bankruptcy classification errors in the 1980s: An empirical analysis of Altman's and Ohlson's models. Review of accounting Studies, 1(4), 267-284.

Bellovary, J. L., \& Giacomino, D. E. (2007). A review of bankruptcy prediction studies: 1930-Present. Accounting Faculty Research and Publications, 33, 1-42.

Bhatia, M., \& Mulenga, M. J. (2019). Value relevance of accounting information: Comparative study of Indian public and private sector banks. International Journal of Indian Culture and Business Management, 18(1).

Bredart, X. (2014). Bankruptcy prediction model using neural networks. Accounting and Finance Research, 3(2).

Burke, A. (2007). Neutralizing cognitive bias: An invitation to prosecutors. NYU Journal of Law E Liberty, 2, 512-530.

Chintala, B. (2017). A comparative study on financial performance of selected public and private sector banks in India. Journal of Commerce and Trade, 11, 89-96.

Coelho, L., \& John, K. (2011). Gambling on the market: who buys the stock of bankrupt firms? In BFWG April 2011 conference Cass Business School, $1-53$.

Cole, S. A., Sampson, T. A., \& Zia, B. H. (2009). Financial literacy, financial decisions, and the demand for financial services: evidence from India and Indonesia (pp. 09-117). Cambridge, MA: Harvard Business School.

Constand, R., Yazidpour, R. (2010). Predicting firm failure: A behavioral finance perspective. The Journal of Entrepreneurial Finance, 14(3), 90-104.

Du Jardin, P. (2010). Predicting bankruptcy using neural networks and other classification methods: The influence of variable selection techniques on model accuracy. Neurocomputing, 73(10-12), 2047-2060.

Edward, A. (1968). Financial ratios, discriminant analysis and the prediction of corporate bankruptcy. The Journal of Finance, 23(4).

Feng, M., Shaonan, T., \& Ling, M. (2019). Deep learning models for 
bankruptcy prediction using textual disclosures. European Journal of Operational Research, 274(2), 743-758.

Gautam, J., Joshi, N., Singh, S., \& Kumar, D. (2014). Analyzing performance of banks \& predicting bank failure. SSRN, 1-15.

Ghosh, B., \& Srinivasan, P. (2014). BSE 100 market capitalization follows sentiment of investors or technical methods- An analytical study. Scholarly Research Journal for Humanity Science and English Language, 1(3), 400-404.

Ghosh, B., \& Srinivasan, P. (2015). Detection of sentiment in CNX Nifty-An investigative attempt using probabilistic neural network. International Journal of Business Quantitative Economics and Applied Management Research, 1(12), 1-11.

Ghosh, B., Krishna, M. C., \& Ramachandran, T. (2016). PSU bank modelingA comparative modeling approach involving Artificial Neural Network and Panel Data Regression. Asian Journal of Research in Business Economics and Management, 6(6), 27-36.

Ghosh, B. (2017). Bankruptcy modelling of indian public sector banks: Evidence from neural trace. International Journal of Applied Behavioral Economics, 6(2), 15.

Ghosh, B., Roux, C. Le, \& Ianole, R. (2017). Fear estimation-evidence from BRICS and UK. International Journal of Applied Business and Economic Research, 15(4), 15.

Hamid, S. A. (2004). Primer on using neural networks for forecasting market variables. The Center for Financial Studies.

Janger, E. J., Block-lieb, S., Block-lieb, S., \& Janger, E. J. (2006). The Myth of the Rational Borrower: Behaviorism, Rationality and the Misguided Reform of Bankruptcy Law Bankruptcy Law. Texas Law Review, 84, 1481-1565.

Jardin, P. Du. (2008). Bankruptcy prediction and neural networks: the contribution of variable selection methods. Research Gate.

John, Y., Hilscher, J. D., \& Szilagyi, J. (2010). Predicting Financial Distress and the Performance of Distressed Stocks Predicting Financial Distress and the Performance of Distressed Stocks. Digital Access to Scholarship at Harvard.

Jouzbarkand, M., Aghajani, V., \& Khodadabi, M. (2013). Creation Bankruptcy Prediction Model with Using Ohlson and Shirata Models. International Proceedings of Economics Development and Research, 54(1), 15 .

Karim, R. Al. (2013). An Evaluation of Financial Performance of Private Commercial Banks in An Evaluation of Financial Performance of Private Commercial Banks in Bangladesh: Ratio Analysis. Journal of Business Studies Quarterly, 5(2), 65-77.

Kasgari, A. A., \& Ebadi, F. (2013). The Bankruptcy Prediction by Neural 
Networks and Logistic Regression. International Journal of Academic Research in Accounting, Finance and Management Sciences, 3(4), 146-152.

Kumar, M., Goel, V., Jain, T., \& Singhal, S. (2018). Neural network approach to loan default prediction. International Research Journal of Engineering and Technology (IRJET), 5(4), 4-7.

Li, Y., \& Ma, W. (2011). Applications of Artificial Neural Networks in Financial Economics: A Survey. In 2010 International Symposium on Computational Intelligence and Design.

López-de-Foronda, O., \& Pastor-Sanz, I. (2000). Predicting bankruptcy using neural networks in the current financial crisis: A study of U.S. commercial banks. SSRN Electronic Journal.

M, B. V., \& Chakraborty, S. (2017). Efficiency of private sector banks performance comparison between old and new generation private sector banks. RUAS-JMC, 03(02), 6-10.

Malyadri, P., \& Sirisha, S. (2015). An analytical study on trends and progress of Indian banking industry business \& financial affairs. Journal of Business $\mathcal{E}$ Financial Affairs, 4(1), 1-7.

Mansouri, A., Nazari, A., \& Ramazani, M. (2016). A comparison of artificial neural network model and logistics regression inprediction of companies' bankruptcy- A case study of Tehran stock exchange. International Journal of Advanced Computer Research, 6(24), 81-92.

Motamedi, P. (2013). Investigating different factors influencing on return of private banks. Management Science Letters, 3, 2467-2472.

Murari, K. (2012). Insolvency risk and Z-Index for Indian banks: A probabilistic interpretation of bankruptcy. IUP Journal of Bank Management, 11(3), 7-21.

Nadine, D. M. M. (2001). Bankruptcy prediction: Literature survey of the last ten years.

Naidu, PG. and Govinda, K. (2018). Bankruptcy prediction using neural networks. In Proceedings of the 2nd International Conference on Inventive Systems and Control, ICISC 2018 (pp. 248-251).

Ohlson, A, J. (1980). Financial ratios and the probabilistic prediction of bankruptcy. Journal of Accounting Research, 18(1).

Pandey, A. (2016). The Indian insolvency and bankruptcy bill: Sixty years in the making. In Munich Personal RePEc Archive, 8, 26-34.

Piramuthu, S., Ragavan, H., \& Shaw J., M. (1998). Using feature construction to improve the performance of neural networks. Management Science, 44(3), 285-432.

Raj, U. (2019). Prediction of bankruptcy risk in Indian banks: An application of Altman' s model. International Journal of Research (IJR), 1-23.

Samek, W., \& Montavon, G. (2018). Methods for interpreting and understanding deep neural networks. Digital Signal Processing, 73, 1-18.

Selvamuthu, D., Kumar, V., \& Mishra, A. (2019). Indian stock market 
prediction using artificial neural networks on tick data. Financial Innovation, 5(1), 16.

Singh, S., \& Makkar, A. (2015). Assessing the probability of financial distress. Journal of Business Thought, 5, 126-137.

Sun, L. (2007). A re-evaluation of auditors' opinions versus statistical models in bankruptcy prediction. Review of Quantative Finance and Accounting, 28(1), 55-78.

Tam, K. Y. (1991). Neural network models and the prediction of bank bankruptcy. Omega, 19(05), 429-445.

Vardar, G. (2013). Efficiency and stock performance of banks in transition countries: Is there a relationship? International Journal of Economics and Financial Issues, 3(2), 355-369.

Veganzones, D., Severin, E. (2018). An investigation of bankruptcy prediction in imbalanced datasets. Decision Support Systems, 112, 111124.

Wilson, R. 1., \& Sharda, R. (1994). Bankruptcy prediction using neural networks. Decision Support Systems, 11(05), 545-557.

Wu, Y., Gaunt, C., \& Gray, S. (2010). A comparison of alternative bankruptcy prediction models. Journal of Contemporary Accounting $\mathcal{E}$ Economics, 6(1), 34-45. 
Ushus-Journal of Business Management, Vol. 19, No. 3 ISSN 0975-3311

\section{Annexure 1}

Training and test data (graph)

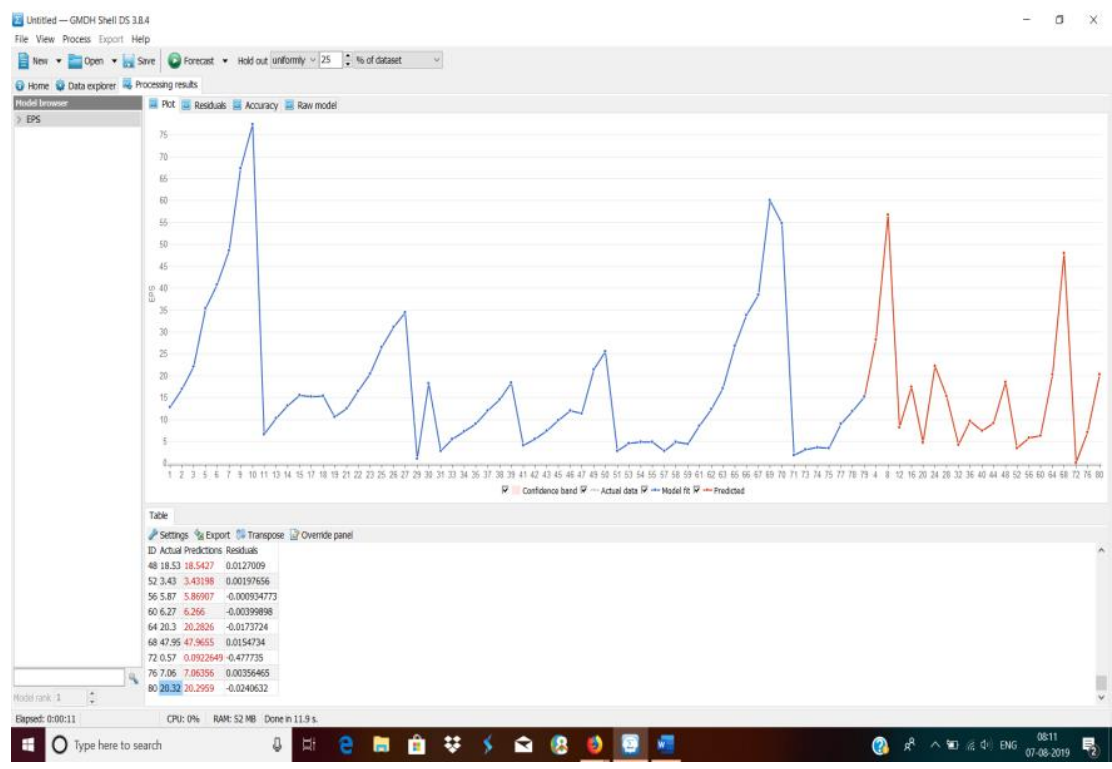

Distribution of residuals

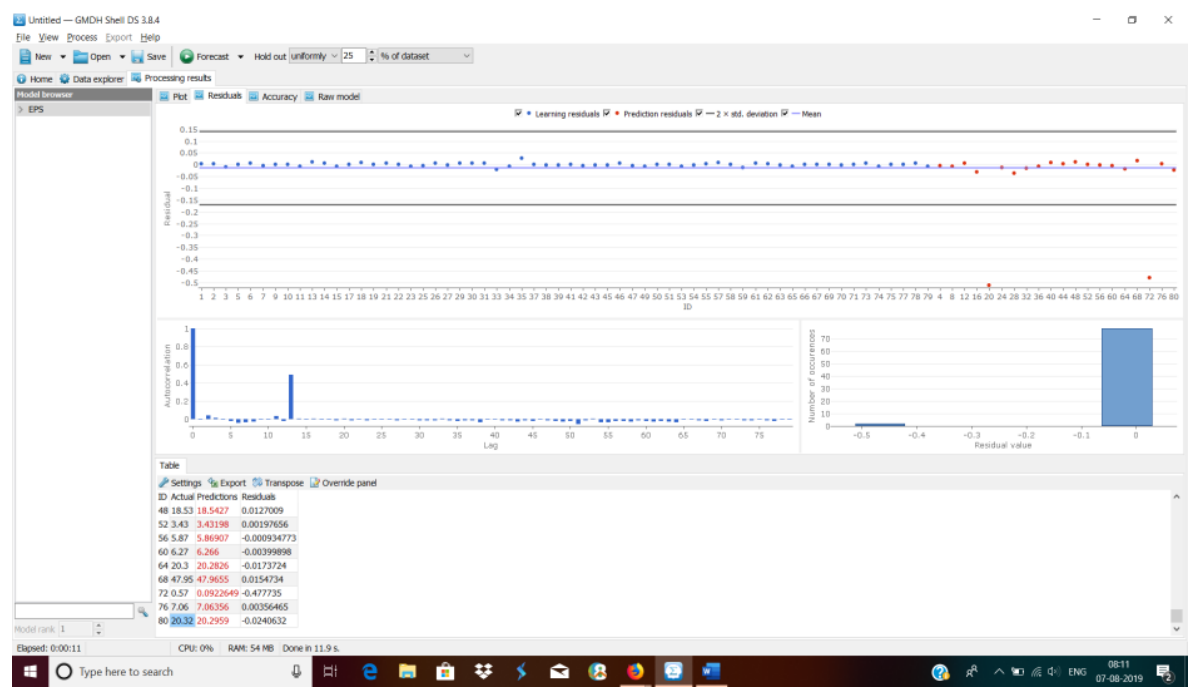

